\title{
Gammaherpesvirus BoHV-4 infects bovine respiratory epithelial cells mainly at the basolateral side
}

\author{
Bo Yang ${ }^{1,2}{ }^{0}$, Jiexiong Xie ${ }^{1}$, Jolien Van Cleemput ${ }^{1}$, Ruifang Wei ${ }^{1}$, Geert Opsomer $^{2}$ and Hans J. Nauwynck ${ }^{1^{*}}$
}

\begin{abstract}
Bovine herpesvirus 4 (BoHV-4) is a gammaherpesvirus that is widespread in cattle. However, only a few studies about the pathogenesis of BoHV-4 primary infection have been reported. In the present study, ex vivo models with bovine nasal and tracheal mucosa explants were used to study the cellular BoHV-4-host interactions. Infection was observed in nasal but not in tracheal epithelial cells. To find a possible correlation between the integrity and restricted infection of the respiratory epithelium, both nasal mucosal and tracheal explants were treated with EGTA, a drug that disrupts the intercellular junctions, before inoculation. The infection was analyzed based on the number of plaques, plaque latitude and number of infected single cells, as determined by immunofluorescence. BoHV-4 infection in nasal mucosal explants was enhanced upon opening the tight junctions with EGTA. Infection in tracheal explants was only found after treatment with EGTA. In addition, primary bovine respiratory epithelial cells (BREC) were isolated, grown at the air-liquid interface and infected either at the apical or basolateral side by BoHV-4. The results showed that BoHV-4 preferentially bound to and entered BREC at the basolateral surfaces of both nasal and tracheal epithelial cells. The percentage of BoHV-4 infection was significantly increased both from nasal and tracheal epithelial cells after treatment with EGTA, which indicates that the BoHV-4 receptor is mainly located at the basolateral surface of these cells. Thus, our findings demonstrate that integrity of the respiratory epithelium is crucial in the host's innate defense against primary BoHV-4 infections.
\end{abstract}

\section{Introduction}

Bovine herpesvirus 4 (BoHV-4) is a member of the family Herpesviridae, subfamily Gammaherpesvirinae, genus Rhadinovirus [1]. BoHV-4 was isolated for the first time from animals with respiratory and ocular signs in Europe in 1963 [2]. BoHV-4 is widespread in bovine and remains latent and asymptomatic in the vast majority of infected animals. Viral replication can be reactivated by corticosteroids or stress, both factors present at calving [3]. Although BoHV-4 has been demonstrated in many tissues, accumulated evidence suggests that cells of the monocyte/macrophage lineage are the main site of persistence in both natural and experimental hosts [4].

\footnotetext{
*Correspondence: hans.nauwynck@ugent.be

${ }^{1}$ Department of Virology, Parasitology and Immunology, Faculty of Veterinary Medicine, Ghent University, Salisburylaan 133, 9820 Merelbeke, Belgium

Full list of author information is available at the end of the article
}

There are several innate mucosal barriers between gammaherpesviruses and their hosts, which include the mucus layer, the mucociliary escalator, antimicrobial peptides and firm intercellular connections [5]. The airway surface liquid (ASL), often referred to as mucus, is the first layer of defense against incoming pathogens through mucociliary clearance. Intercellular junctions (ICJ) of the respiratory epithelium are crucial in the host's innate defense against primary infection with alphaherpesvirus equine herpesvirus type 1 (EHV-1) [6]. Therefore, we hypothesized that intercellular junctions (ICJ) may play a similar important role for gammaherpesviruses in protecting the respiratory mucosa from primary replication. ICJ are specialized regions of contact between the plasma membranes of adjacent cells and form the apical cell domain, separating the external environment from the basolateral cell domains, which contacts the underlying cells and systemic vasculature [7]. 
Virus binding and subsequent entry may occur selectively at either the apical or basolateral domains of polarized cells, due to the specific expression of receptors required for binding and internalization. Some viruses, such as simian virus, hepatitis A virus and West Nile virus preferentially infect polarized cells at the apical surfaces [8-10], while vesicular stomatitis virus (VSV), Semliki Forest virus and EHV-1 prefer basolateral surfaces [6, $11,12]$. In respiratory epithelial cells, polarity of infection and the importance of ICJ have not been studied for gammaherpesviruses. Previous studies with a continuous cell line do not really reflect the in vivo situation $[13,14]$. Therefore, a respiratory mucosal explant model, which mimics the in vivo situation, was used to investigate the importance of ICJ for the respiratory infection of the gammaherpesvirus BoHV-4. In addition, primary bovine respiratory epithelial cells (BREC) were isolated and cultivated on transwells to illustrate the polarity of BoHV-4 binding and subsequent viral replication.

In a previous study, ex vivo models with bovine genital tract mucosa explants were set up to elucidate the mucosal dissemination and invasion of BoHV-4 [15]. BoHV-4 replicates in the epithelial cells of uterus, cervix and vagina in a plaquewise manner and does not cross the basement membrane. Instead, it hijacks individual $\mathrm{CD} 172 \mathrm{a}^{+}$monocytic cells to invade the underlying connective tissue. During this migration, the BoHV-4 replication is silenced, because fibrocytes do not become infected. When BoHV-4 become produced in connective tissue (e.g. upon reactivation), fibrocytes may become infected and may eventually lead to pathological processes [15]. In the present study, respiratory mucosal explants and BREC were used to describe the invasion mechanism of gammaherpesvirus BoHV-4.

\section{Materials and methods}

\section{Virus strain}

The BoHV-4 strain V.test was used in this study, which belongs to the European clade of BoHV-4 strains. It was originally isolated from an infertile bull's testicle. The strain V.test had previously received an unknown number of passages. The virus was passaged three times in Madin Darby Bovine Kidney (MDBK) cells in our laboratory.

\section{Tissue collection and processing}

The nasal and tracheal mucosae were collected from healthy cattle at the local slaughterhouse and were immediately placed in phosphate buffered saline (PBS), supplemented with $1000 \mathrm{U} / \mathrm{mL}$ penicillin (Continental Pharma, Puurs, Belgium), $1 \mathrm{mg} / \mathrm{mL}$ streptomycin (Certa, Braine l'Alleud, Belgium), $1 \mu \mathrm{g} / \mathrm{mL}$ gentamycin (Invitrogen, Paisley, UK) and $5 \mu \mathrm{g} / \mathrm{mL}$ fungizone (Bristol-Myers Squibb, New York, USA) on ice for transportation to the laboratory. Nasal septum mucosal explants and trachea mucosal explants were prepared as previously described [15]. Primary bovine nasal and tracheal epithelial cells were isolated and cultured as described by Van Cleemput et al. [6].

\section{Disruption of intercellular junctions Respiratory mucosa explants}

Nasal and tracheal mucosa explants were cultured $24 \mathrm{~h}$ in medium [15]. Afterwards, the apical surface of the epithelial cells was exposed for $1 \mathrm{~h}$ at $37^{\circ} \mathrm{C}$ to $8 \mathrm{mM}$ ethylene glycol tetra-acetic acid (EGTA) (VWR International, Leuven, Belgium) as described by Galen et al. [16]. PBS was used as a control. Finally, explants were washed 3 times to remove excess of EGTA before inoculation. To determine the viability of the cells in the explants after treatment with EGTA, an in situ Cell Death Detection Kit (Roche Diagnostics Corporation, Basel, Switzerland) was used based on terminal deoxynucleotidyl transferase dUTP nick end-labeling (TUNEL).

\section{Respiratory epithelial cells}

Nasal and tracheal epithelial cells were grown in transwells. The medium from the wells was changed every day until confluency. After that, the cells were treated with $8 \mathrm{mM}$ EGTA in PBS for $30 \mathrm{~min}$ prior to inoculation; PBS was used as a control. The viability of the cells was assessed by ethidium monoazide bromide (EMA) staining. EGTA treatment did not cause a significant cell death.

\section{Virus inoculation}

\section{Respiratory mucosal explants}

After $24 \mathrm{~h}$ of cultivation of explants at the air-liquid interface, nasal and tracheal explants were treated with EGTA to dissociate ICJ or PBS as described above. Explants were submerged in $0.5 \mathrm{~mL}$ of BoHV-4 containing medium $\left(10^{7} \mathrm{TCID}_{50} / \mathrm{mL}\right)$ and incubated for $1 \mathrm{~h}$ $\left(37{ }^{\circ} \mathrm{C}, 5 \% \mathrm{CO}_{2}\right)$. Before explants were placed back on the gauze, they were washed three times with PBS. The inoculated tissues were collected at $0 \mathrm{~h}, 24 \mathrm{~h}, 48 \mathrm{~h}$ and 72 hours post-infection (hpi). All gathered explants were embedded in cryoprotection medium [Methocel ${ }^{\circledR}$, Fluka (Sigma)] and then frozen at $-70{ }^{\circ} \mathrm{C}$.

\section{Respiratory epithelial cells}

After respiratory epithelial cells became confluent in a transwell cell culture system, the cells were treated with EGTA or mock treated with PBS. Afterwards, the cells were inoculated with $100 \mu \mathrm{L}$ of BoHV-4 $(\mathrm{MOI}=2)$ at either the apical or the inverted basolateral surface for $1 \mathrm{~h}\left(37^{\circ} \mathrm{C}, 5 \% \mathrm{CO}_{2}\right)$. The cells were washed 3 times with DMEM/F12. Fresh respiratory epithelial cell culture 
medium was added to each well and cells were further incubated at the air-liquid interface. The cells were collected at $0 \mathrm{~h}, 24 \mathrm{~h}, 48 \mathrm{~h}$ and $72 \mathrm{hpi}$ and fixed in methanol for $20 \mathrm{~min}$ at $-20^{\circ} \mathrm{C}$ and stored dry at $-20^{\circ} \mathrm{C}$ until staining. The supernatant was used for titration.

\section{Binding assay}

The virus-binding studies were carried out to characterize the attachment of BoHV-4 to respiratory epithelial cells. After treated with EGTA or PBS, the cells were chilled on ice for $5 \mathrm{~min}$ and washed 3 times with cold PBS. Then, BREC were inoculated at an MOI of 10 with BoHV-4 at either the apical or inverted basolateral surfaces for $1 \mathrm{~h}$ at $4{ }^{\circ} \mathrm{C}$. The cells were washed 3 times with cold PBS to remove unbound virus and then fixed in methanol for $10 \mathrm{~min}$. A primary mouse monoclonal IgG2a antibody (Mab35) against the early-late glycoprotein complex gp6/ gp10/gp17 of BoHV-4 (1:1000 in PBS) was added. Next, cells were washed and incubated in a secondary goat anti-mouse IgG2a Alexa fluor ${ }^{\circledR} 488$ (Invitrogen) (1:200). Nuclei were counterstained with Hoechst $33342(10 \mu \mathrm{g} /$ $\mathrm{mL}$; Invitrogen) for $10 \mathrm{~min}$ at room temperature and the transwell was mounted with glycerol-DABCO. The total number of virus particles attached to the apical or basolateral surfaces was counted. The percentage of BREC with bound BoHV-4 particles was calculated based on the number of cells with viral particles bound on the plasma membrane of 300 randomly selected cells.

\section{Virus titration}

BREC culture medium were collected at $0 \mathrm{~h}, 24 \mathrm{~h}, 48 \mathrm{~h}$ and $72 \mathrm{hpi}$ for virus titration. MDBK cells were inoculated for $1 \mathrm{~h}\left(37{ }^{\circ} \mathrm{C}, 5 \% \mathrm{CO}_{2}\right)$ with serial 10 -fold dilutions $\left(10^{0}\right.$ to $10^{-7}$ in quadruplicate) of culture medium of BoHV-4 and mock inoculated BREC. Afterwards, MDBK cells were observed daily for cytopathic effect (CPE) for 7-9 days. The virus titer was calculated using the method of Reed and Muench [17].

\section{Immunofluorescent staining and confocal microscopy Respiratory mucosal explants}

At least 100 cryosections $(20 \mu \mathrm{m})$ were made for each condition of both BoHV-4 and mock inoculated respiratory mucosae. Cryosections were fixed in methanol $\left(-20{ }^{\circ} \mathrm{C}, 100 \%\right)$ for $20 \mathrm{~min}$ and washed in PBS. Afterwards, they were incubated with a primary mouse monoclonal IgG2a antibody (Mab35) against BoHV-4 for $1 \mathrm{~h}$ at $37^{\circ} \mathrm{C}$, followed by an incubation with a secondary goat anti-mouse IgG2a Alexa fluor ${ }^{\circledR} 488$ (Invitrogen) (1:200).

\section{Respiratory epithelial cells}

In order to identify the BoHV-4 infected respiratory epithelial cells, double immunofluorescence stainings were performed using different cell markers. Cells were incubated with a primary mouse monoclonal IgG2a antibody (Mab35) against BoHV-4 for $1 \mathrm{~h}$ at $37{ }^{\circ} \mathrm{C}$, followed by an incubation with a secondary goat anti-mouse IgG2a Alexa fluor ${ }^{\circledR} 594$ (Invitrogen) (1:200). Afterwards, a monoclonal mouse IgG1 anti-human cytokeratin (Dako, Glostrup, Denmark) (1:50 in PBS) was added, followed by a secondary goat anti-mouse IgG1 FITC $^{\circledR}$ (Abcam, Cambridge, UK) (1:200 in PBS) to stain epithelial cells. Finally, nuclei were counterstained with Hoechst $33342(10 \mu \mathrm{g} /$ $\mathrm{mL}$; Invitrogen) for $10 \mathrm{~min}$ at room temperature and cells were mounted with glycerol-DABCO. Analysis was performed by a TCS SPE confocal system (Leica Microsystems $\mathrm{GmbH}$, Wetzlar, Germany).

\section{Identification of single infected cells in the lamina propria} In order to identify the single BoHV-4 infected cells after inoculation, a double immunofluorescence staining was performed using different markers. Firstly, cryosections were incubated by a mixture of a primary mouse monoclonal IgG2a antibody (Mab35) against BoHV-4 mixed and a primary monoclonal mouse IgG1 antibody DH59B (VMRD Inc., Pullman) directed against CD172a cells of the monocyte lineage for $1 \mathrm{~h}$ at $37{ }^{\circ} \mathrm{C}$, followed by an incubation with a mixture of a secondary goat anti-mouse IgG2a Alexa fluor ${ }^{\circledR} 594$ (Invitrogen) and a secondary goat anti-mouse IgG1 FITC (Abcam, Cambridge, UK). Afterwards, nuclei were counterstained with Hoechst 33342 $(10 \mu \mathrm{g} / \mathrm{mL}$; Invitrogen) for $10 \mathrm{~min}$ at room temperature and slides were mounted with glycerol-DABCO. Analysis was performed by a TCS SPE confocal system (Leica Microsystems GmbH, Wetzlar, Germany).

\section{Statistical analysis}

Data were statistically processed by Graphpad Prism 5.0 (GraphPad Software, Inc., San Diego, CA, USA) for analysis of variance (ANOVA). The data are represented as means with standard deviation (SD) of three independent experiments. Results with $p$ values of $<0.05$ were considered significant.

\section{Results \\ BoHV-4 infects bovine nasal but not tracheal mucosa explants}

BoHV-4 dissemination was examined in the established bovine respiratory mucosa explant system. Nasal and tracheal mucosae from three different animals were included and inoculated with BoHV-4. The explants were collected at different time points $(0 \mathrm{~h}, 24 \mathrm{~h}, 48 \mathrm{~h}$ and 72 hpi).

For the nasal explants, BoHV-4 positive cells were found at all collected time points post-inoculation. At $24 \mathrm{hpi}$, single positive cells or cluster of a few cells were 
observed in the epithelium and lamina propria. BoHV-4 positive plaques were detected in the epithelium at 48 and $72 \mathrm{hpi}$. The plaque did not cross the basement membrane (Figure 1). No infection was observed in the tracheal explants. These results show that BoHV-4 infects nasal but not tracheal mucosa explants.

\section{BoHV-4 cell tropism after inoculation in the lamina propria} To better understand the cell tropism of BoHV-4 after inoculation, double immunofluorescent stainings were performed on the nasal mucosa explants of the respiratory tract at $24 \mathrm{~h}$ and $48 \mathrm{hpi}$ (Figure 2A). At $24 \mathrm{hpi}$, the percentage of infected cells in the epithelium that were identified as cytokeratin ${ }^{+}$was $90.2 \pm 8.4 \%$. A minority of infected cells was characterized as $\mathrm{CD} 172 \mathrm{a}^{+}$in the epithelium. In the lamina propria, $83.3 \pm 15.2 \%$ of the infected cells were $\mathrm{CD} 172 \mathrm{a}^{+}$cells. Similar results were obtained at $48 \mathrm{hpi}$. The number of infected cells in the lamina propria at $48 \mathrm{hpi}$ was not increased compared to the number at $24 \mathrm{hpi}$ (Figures $2 \mathrm{~B}$ and $\mathrm{C}$ ). BoHV-4 might use $\mathrm{CD} 172 \mathrm{a}^{+}$monocytic cells to cross the basement membrane to reach internal target organs.

\section{EGTA can disrupt respiratory epithelial intercellular junctions}

The intercellular spaces in the respiratory epithelium of both nasal and tracheal mucosa explants increased after treatment with $8 \mathrm{mM}$ EGTA, but not after treatment with PBS. Representative images of cryosections stained with modified Wright-Giemsa (Diff-Quick, Fisher Diagnostics, Newark, DE, USA) are shown in Figure 3. Cell viability in the respiratory mucosa explants did not significantly drop after treatment with 8 mM EGTA compared with control PBS based on TUNEL-staining (Additional file 1). EGTA treatment disrupts intercellular junctions of respiratory epithelial cells without causing significant cell death.

\section{Intercellular junctions protect respiratory mucosal explants to a certain extent from BoHV-4 infection} The number of plaques, plaque latitude and number of single cells were determined after treatment with EGTA or control PBS. Representative pictures of nasal and tracheal mucosa explants are shown in Figures $4 \mathrm{~A}$ and $5 \mathrm{~A}$, respectively. As shown in Figures $4 \mathrm{~B}$ and $5 \mathrm{~B}$, the number of plaques per 100 cryosections of nasal mucosa explants increased from $5 \pm 3$ to $6 \pm 3$ $(p=0.94)$ at $48 \mathrm{~h}$ and $9 \pm 4$ to $14 \pm 6(p=0.15)$ at $72 \mathrm{hpi}$ by treatment with EGTA. For tracheal mucosa explants, BoHV-4 infection was only found after treatment with EGTA. The number of plaques per 100 cryosections was $2 \pm 2$ at $48 \mathrm{~h}$ and $4 \pm 2$ at $72 \mathrm{hpi}$.

The plaque latitude is indicative for the lateral viral spread in the explant. For nasal mucosa explants, the average latitude increased from $64.3 \pm 12.9 \mu \mathrm{m}$ to $81.7 \pm 18.8 \mu \mathrm{m}(p=0.99)$ at $48 \mathrm{~h}$ and $173.0 \pm 65.8 \mu \mathrm{m}$ to $210.0 \pm 68.7 \mu \mathrm{m}(p=0.84)$ at $72 \mathrm{hpi}$ by treatment with EGTA. For tracheal mucosal explants, the average plaque latitude in the EGTA treated explants was $52.0 \pm 14.4 \mu \mathrm{m}$ at $48 \mathrm{hpi}$ and $76.7 \pm 13.3 \mu \mathrm{m}$ at $72 \mathrm{hpi}$. These results show that the integrity of ICJ protects respiratory mucosal explants to a certain extent from BoHV-4 infection.

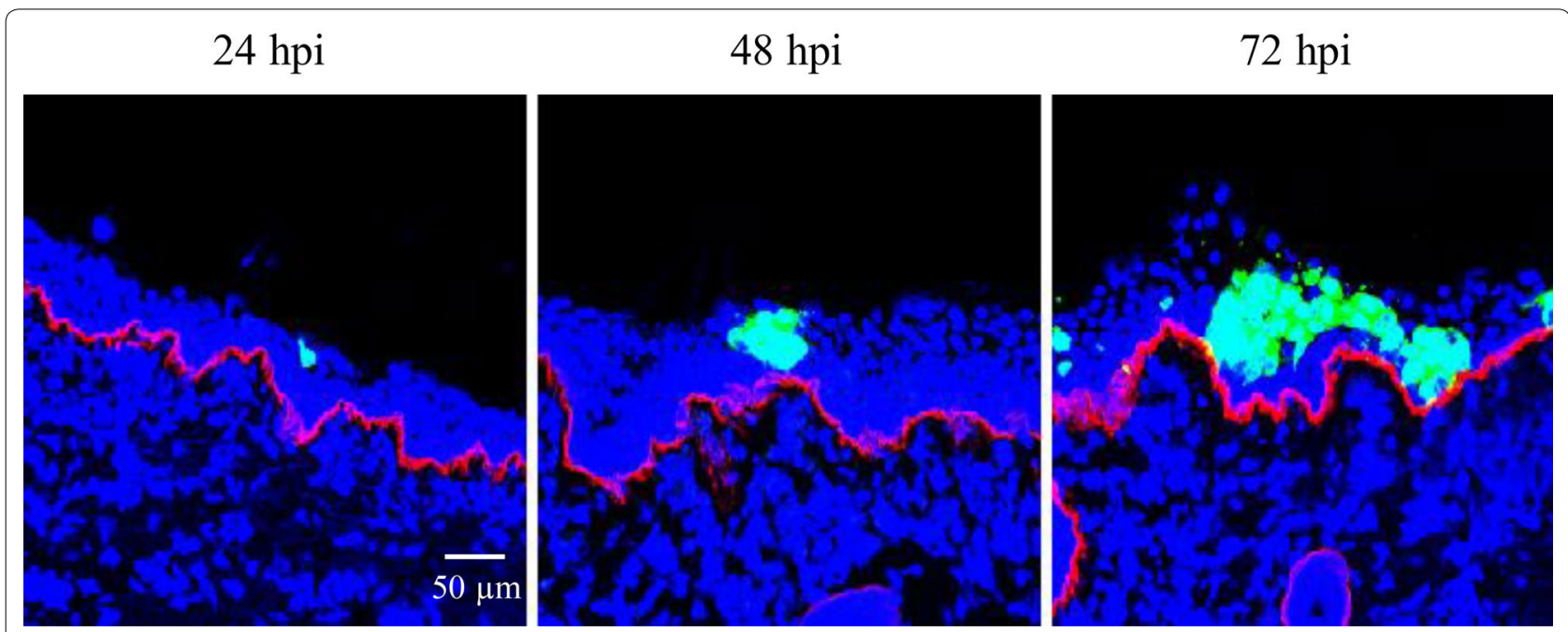

Figure 1 Representative micrographs of BoHV-4 (green) replication at 24, $48 \mathrm{~h}$ and $72 \mathrm{hpi}$ in bovine respiratory nasal mucosa explants. The BM is visualized by mouse anti-collagen VII antibodies and goat anti-mouse Texas Red ${ }^{\circledR}$ conjugate (red). Cell nuclei were counterstained with Hoechst (blue). 


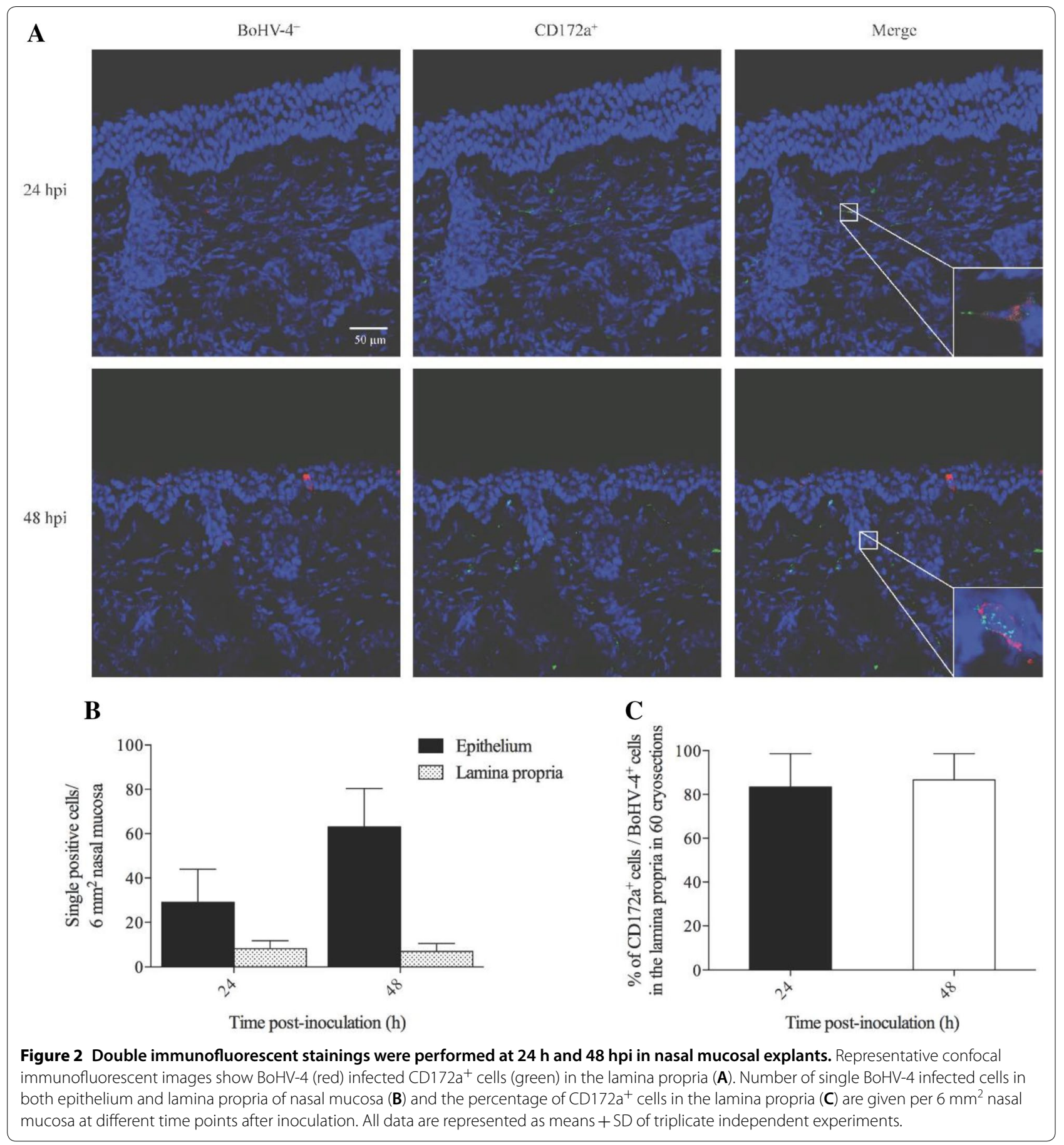

\section{BoHV-4 preferentially infects basolateral surfaces of respiratory epithelial cells}

To investigate whether BoHV-4 preferentially infects either apical or basolateral surfaces of BREC, the percentage of infection in both nasal and tracheal epithelial cells upon apical or basolateral inoculation was evaluated at different time points $(24,48$ and 72 hpi) after treatment with EGTA or PBS (mock). Representative pictures from BREC are shown in Figures $6 \mathrm{~A}$ and $7 \mathrm{~A}$. For nasal epithelial cells, the average percentage of infection was $0.2 \pm 0.1$ at $24 \mathrm{~h}, 1.9 \pm 1.6$ at $48 \mathrm{~h}$ and $4.4 \pm 1.9$ at $72 \mathrm{hpi}$ after mock treatment with PBS and $1.1 \pm 0.6$ at $24 \mathrm{~h}, 4.7 \pm 1.8$ at $48 \mathrm{~h}$ and $15.8 \pm 3.8$ at $72 \mathrm{hpi}$ after treatment with EGTA when 


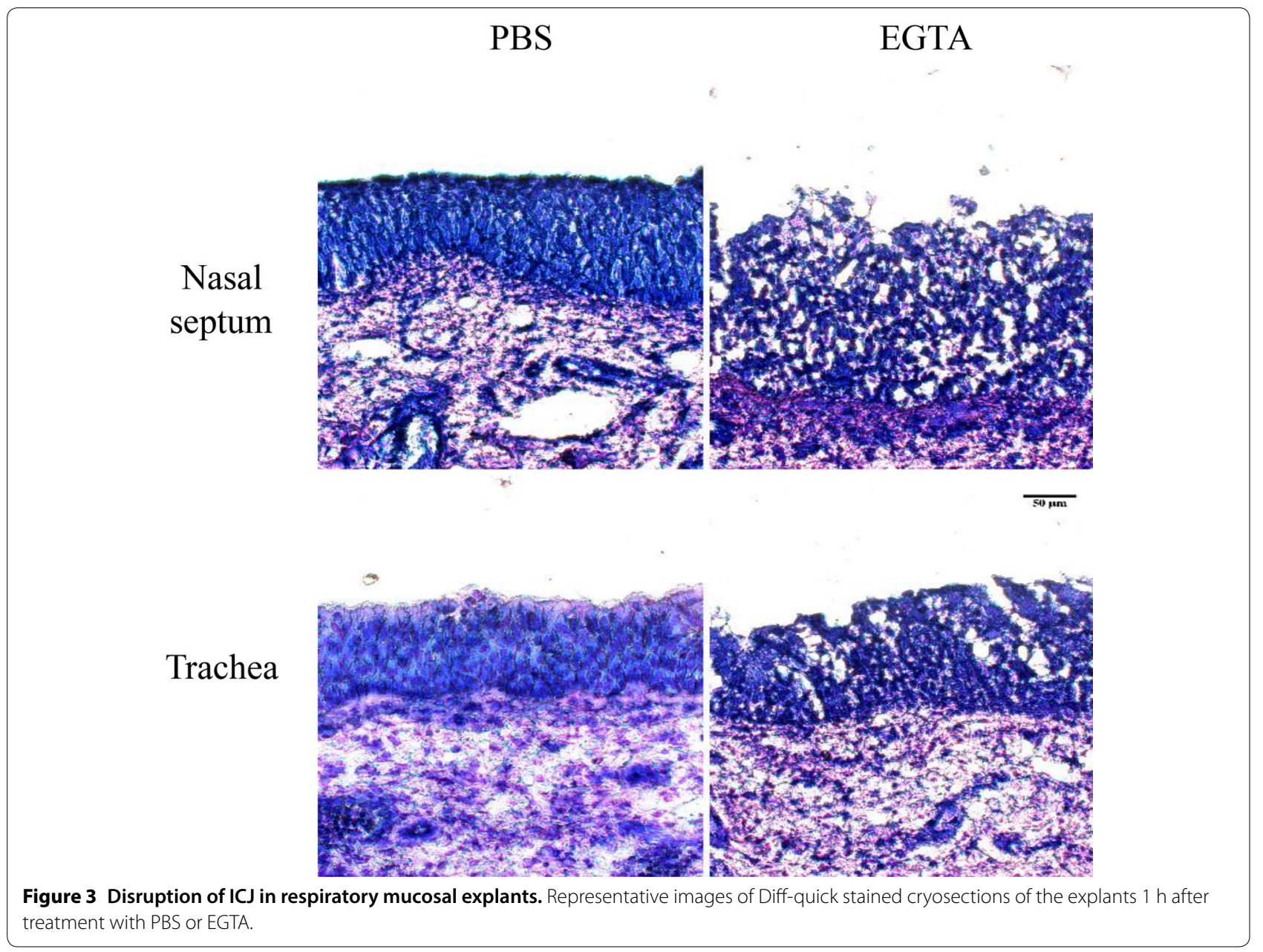

inoculated apically, whereas it was $1.1 \pm 0.5,8.1 \pm 2.8$ and $24.5 \pm 6.1$ after treatment with PBS and $1.4 \pm 0.2$, $8.2 \pm 1.7$ and $27.4 \pm 6.8$ after treatment with EGTA when inoculated basolaterally. For tracheal cells, the average percentage of infection was $0.01 \pm 0.01$ at $24 \mathrm{~h}$, $0.3 \pm 0.2$ at $48 \mathrm{~h}$ and $0.9 \pm 0.4$ at $72 \mathrm{hpi}$ after treatment with PBS and $0.08 \pm 0.02$ at $24 \mathrm{~h}, 0.7 \pm 0.3$ at $48 \mathrm{~h}$ and $4.9 \pm 2.1$ at $72 \mathrm{hpi}$ after treatment with EGTA when inoculated apically, whereas it was $0.2 \pm 0.1,3.8 \pm 0.8$ and $15.1 \pm 5.9$ after treatment with PBS and $0.3 \pm 0.2$, $4.7 \pm 1.8$ and $20.8 \pm 5.3$ after treatment with EGTA when inoculated basolaterally (Figures $6 \mathrm{~B}$ and $7 \mathrm{~B}$ ). The culture medium of inoculated BREC was collected and titrated at different time points in order to get insights in virus production and shedding. The virus titer curves are given in Figures $6 \mathrm{C}$ and $7 \mathrm{C}$. The virus titer increased over time after basolateral inoculation of both nasal and tracheal epithelial cells. For nasal epithelial cells, the virus titer was increased after treatment with EGTA when inoculated apically, compared to treatment with PBS. These results demonstrate that basolateral inoculation of BoHV-4 results in a much higher infection in the respiratory epithelial cells than apical exposure.

\section{Increased epithelial cell susceptibility to BoHV-4 at the basolateral surfaces is correlated with the virus binding step}

BoHV-4 binding to BREC after PBS or EGTA treatment was examined. Representative confocal images of BREC with bound BoHV-4 are shown in Figures 8A and B. The percentage of nasal epithelial cells with BoHV-4 particles after basolateral inoculation $(35.3 \pm 10.0)$ was significantly higher than after apical inoculation $(3.4 \pm 0.7)$, whereas it was $25.6 \pm 3.9$ upon apical inoculation and $37.0 \pm 8.2$ upon basolateral inoculation after treatment with EGTA. Moreover, the percentage of tracheal epithelial cells with BoHV-4 particles after the basolateral inoculation (27.0 \pm 11.5$)$ was significantly higher than after the apical inoculation $(0.7 \pm 0.5)$, whereas it was $10.3 \pm 4.7$ upon apical inoculation and $27.6 \pm 13.4$ upon basolateral inoculation after treatment with EGTA. The 


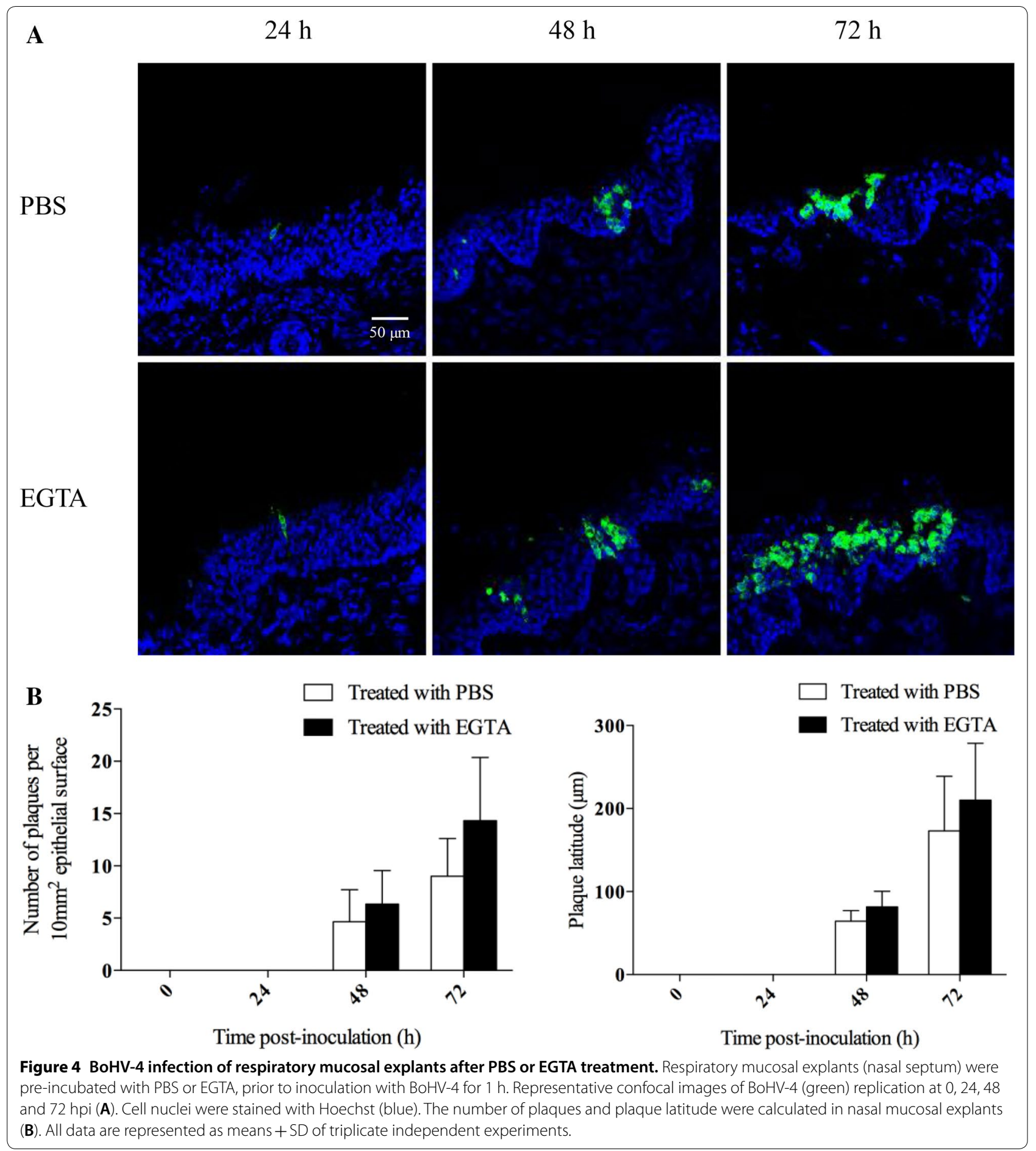

results are shown in Figure $8 \mathrm{C}$ and D. These results illustrate that BoHV-4 preferentially binds to basolateral surfaces of respiratory epithelial cells.

\section{Discussion}

Little is known about the primary replication and dissemination of gammaherpesviruses at the host respiratory mucosal entry port. Getting a better fundamental image on how the virus behaves at its primary replication site will provide insights for prevention and treatment 


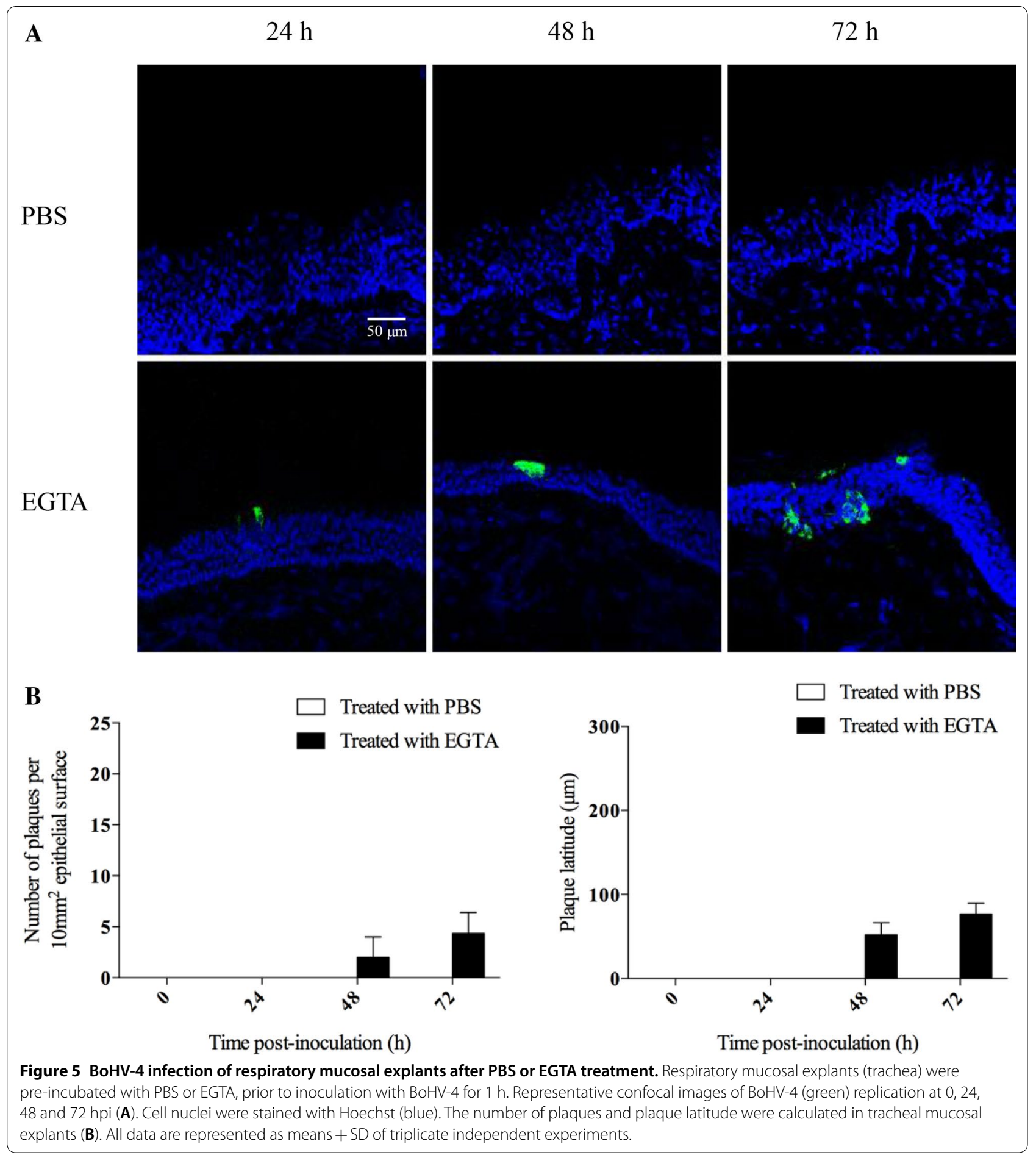

on a rational basis. In the present study, bovine respiratory tract mucosal explants (nasal septum and trachea) and BREC were used for studying the BoHV-4 primary infection in its host. The explant model is the perfect compromise between in vitro cell cultures and in vivo animals. It was demonstrated that BoHV-4 replicates in the nasal mucosa explants, which is in agreement with the in vivo respiratory tract symptoms associated with BoHV-4 infections. Plaques were visible in the epithelium at $48 \mathrm{hpi}$ and they did not cross the basement membrane, which is corresponding with our previous findings in genital tract mucosal explants [15]. In contrast, the 


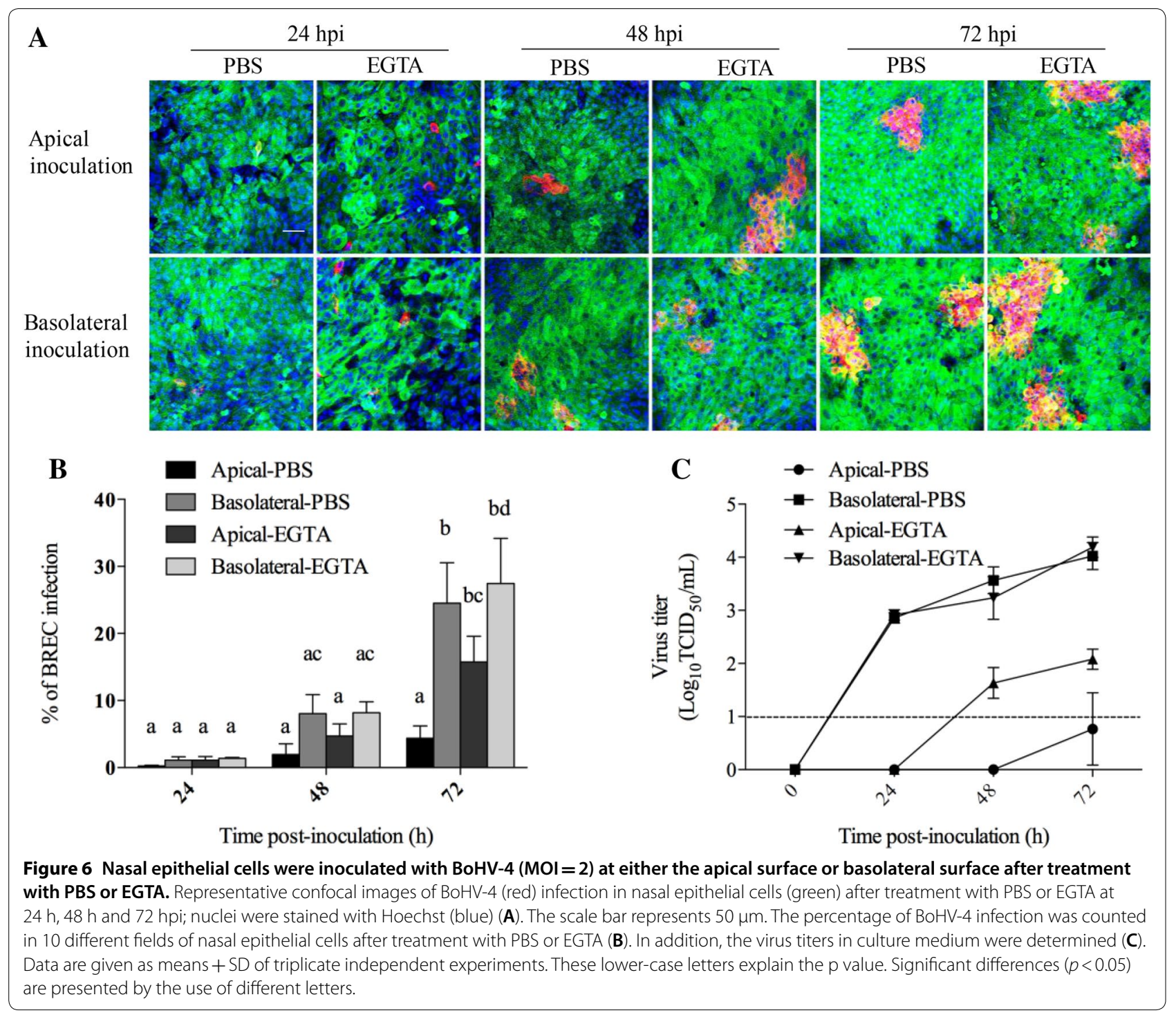

bovine alphaherpesvirus BoHV-1 causes an extensive epithelial plaque formation and exhibits a clear crossing of the basement membrane barrier [18]. The number and size of plaques in the nasal mucosa were slightly larger than in the vagina. This illustrates that BoHV-4 can easily use both the genital and respiratory tract for its first replication and subsequent horizontal transmission. The trachea was not found to be infected at any collection time, which may be due to the absence of apical receptors at the epithelial cells, leading to a state of resistance.

The number of single infected cells in the lamina propria was rather low and most of them were identified as CD $172 \mathrm{a}^{+}$cells. This indicates that BoHV-4 has a strong tropism for cells of the monocyte/macrophage lineage, which has been supported by previous studies [19-21]. Interestingly, Frederico et al. have recently used a homologous mouse model to study how the gammaherpesvirus, murine herpesvirus 4 (MuHV-4), enters the host via the upper respiratory tract [22]. They found and proposed that MuHV-4 first infects epithelial cells, then exploits myeloid cells to reach and finally infect B lymphocytes [22, 23]. BoHV-4 uses alternative splicing to express high levels of gp180 in epithelial cells but reduced levels in myeloid cells to regulate its tropism [21]. A major BoHV-4 envelope protein, gp180, is massively glycosylated [24]. Machiels et al. found that if gp180 is present, it allows efficient infection of glycosaminoglycans-positive [GAG(+)] cells like epithelial cells and if absent, it makes the virus more infectious for glycosaminoglycans-negative [GAG(-)] cells such as monocytes [25]. In our study, epithelial cells are likely the first target of BoHV-4. Next to that, monocyte/ macrophages are being infected and possibly hijack the 


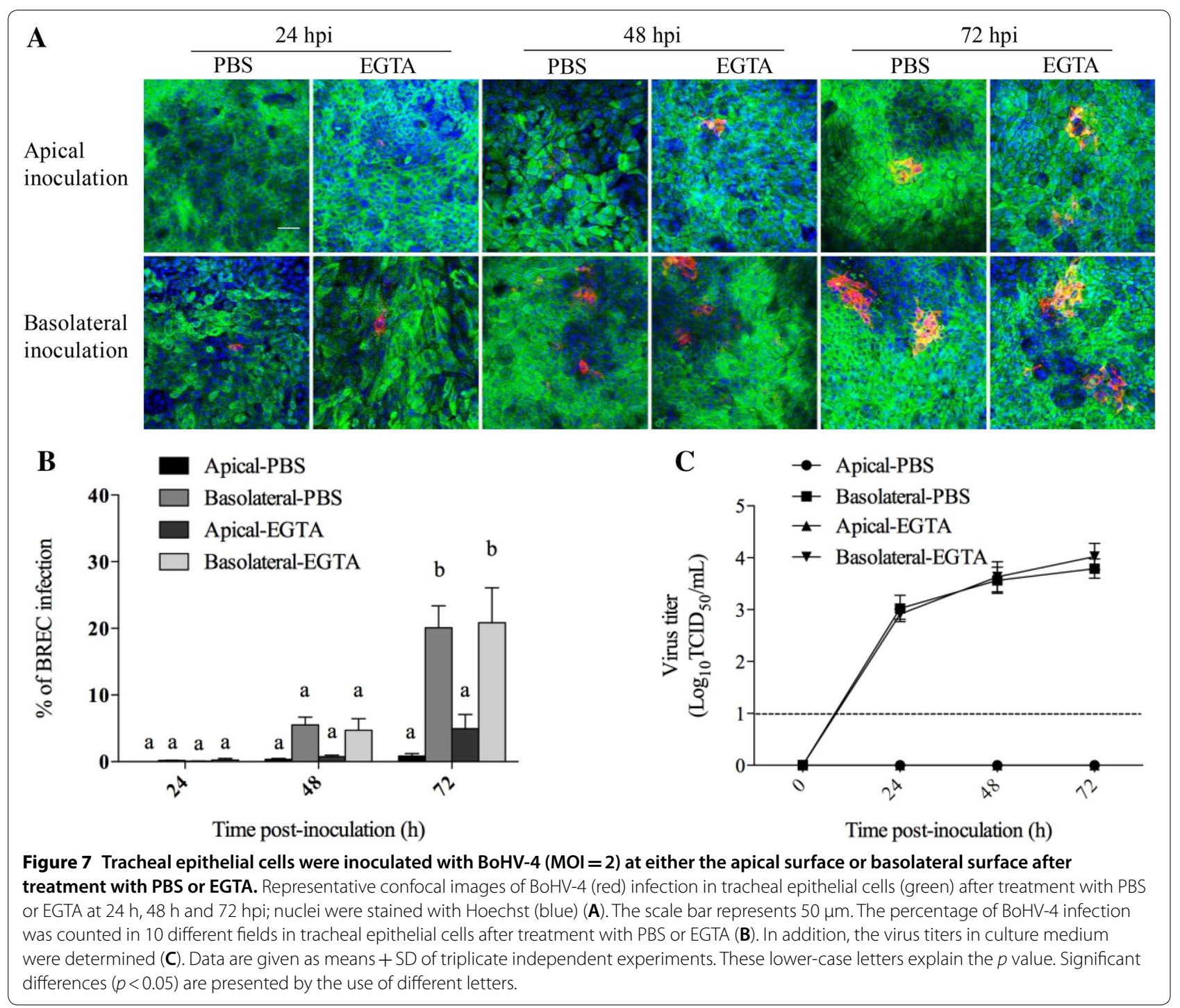

virus to cross the basement membrane, a mechanism previously described for alphaherpesvirus EHV-1 [26].

In order to examine the importance of tight junctions as a barrier for BoHV-4 infection, the respiratory mucosal explants were incubated with EGTA, a drug that disrupts the intercellular junctions. EGTA specifically induces a depletion of calcium ions from the culture medium of polarized epithelial cells which results in rapid splitting of the ICJ [27]. Recently, Van Cleemput et al. used EGTA to disrupt ICJ in equine respiratory mucosal explants and to study the impact on alphaherpesvirus EHV-1 infection [6]. The number of plaques ( $9 \pm 4$ to $14 \pm 6, p=0.15$ ), plaque latitude $(173.0 \pm 65.8 \mu \mathrm{m}$ to $210.0 \pm 68.7 \mu \mathrm{m}$, $p=0.84$ ) and number of single positive cells were enhanced for nasal mucosal explants by treatment with EGTA. BoHV-4 was also only able to infect the tracheal epithelium after disruption of the intercellular junctions.
The infection in the trachea was significantly lower compared to the infection in nasal mucosal explants. In contrast, alphaherpesvirus EHV-1 infection was significantly lower in nasal mucosal explants than in tracheal nasal explants [6].

Since BoHV-4 infection was enhanced after disruption of the respiratory epithelium integrity with EGTA, we hypothesized that its primary binding/entry receptor is mainly located basolaterally. Therefore, BRECs were isolated and inoculated at either apical or basolateral surfaces. We found that BoHV-4 preferentially binds to and infects both nasal and tracheal epithelial cells at basolateral surfaces based on the percentage of infected cells. This is in accordance with our virus shedding when inoculated basolaterally. Virus production was increased after treatment with EGTA when inoculated apically in nasal epithelial cells. Taking together 


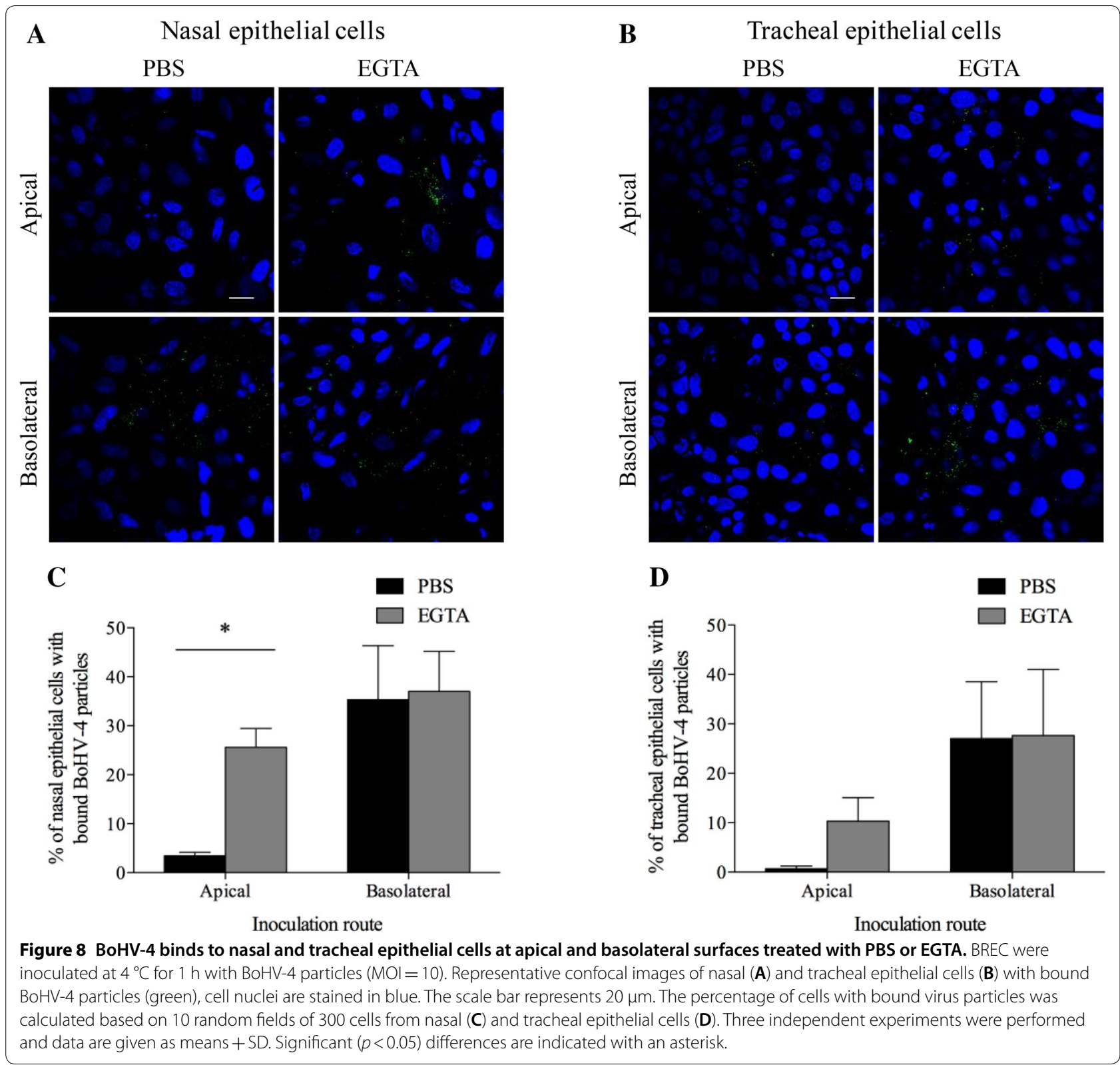

all these findings, we may conclude that BoHV-4 mainly uses a basolateral receptor. It agrees with the fact that single BoHV-4 infections are not causing severe respiratory problems, despite the power of BoHV-4 to replicate in the respiratory epithelial cells. We cannot exclude monocytic cells as primary infected cells that transfer virus to epithelial cells. These monocytic cells can also play a crucial role in transferring the virus upon reactivation. The basolateral localization of the receptor will facilitate the infection of the epithelial cells upon release of the virus from reactivated monocytic cells. One may defend the hypothesis that the epithelial cells are important both for entry and exit of the virus.

It is known that heparan sulfate (HS) serves as the initial receptor for several gammaherpesviruses. Interestingly, heparan sulfate is present on the entire surface of the membrane of undifferentiated cells, but is sequestered at the basolateral cell surface of fully differentiated cells $[28,29]$. The process of adsorption of BoHV-4 is mediated by the interaction of $\mathrm{gB}$ with heparin-like moieties on the cell surface [30]. Furthermore, infection with the murine gammaherpesvirus MuHV-4 depends on virion binding to heparan sulfate via gp70 or $\mathrm{gH} / \mathrm{gL}$ 
[31-33]. The human gammaherpesvirus Kaposi's sarcoma associated herpesvirus (KSHV)-gB mediates viral binding and entry by interacting with cell surface heparan sulfate [34-36]. Previous studies examining the polarity of gammaherpesvirus infections have been conducted in continuous cell lines. To our knowledge, we were the first to use primary polarized respiratory epithelial cells to study gammaherpesvirus infections. Our results showed that the receptor is located at cellular basolateral surfaces and becomes apically accessible when intercellular junctions are impaired. The precise BREC binding/entry receptor for BoHV-4 will be identified in the near future.

In conclusion, the present study demonstrated that gammaherpesvirus BoHV-4 exhibits a specific strategy for respiratory tract invasion and subsequent spread. BoHV-4 infects epithelial cells in the nasal mucosa, rather than in the tracheal mucosa. BoHV-4 preferentially binds to and infects respiratory cells at basolateral surfaces. The virus is not able to directly cross the basement membrane; instead it hijacks $\mathrm{CD} 172 \mathrm{a}^{+}$monocytic cells to reach internal target organs. Taken together, our results shed new light on the primary infection of gammaherpesvirus BoHV-4.

\section{Additional file}

Additional file 1. TUNEL-staining on nasal mucosa explant after treatment with PBS or EGTA. The TUNEL assay revealed no significant apoptotic cells (green marked with arrow bar) were caused after treatment with PBS or EGTA.

\section{Competing interests}

The authors declare that they have no competing interests.

\section{Authors' contributions}

BY designed and performed the experiments, analyzed the data and helped to draft the manuscript. JX and JVC assisted in performing the experiment. RW participated in writing the manuscript. HN and GO conceived and designed the study and helped in writing the manuscript. All authors read and approved the final manuscript.

\section{Acknowledgements}

The authors would like to acknowledge Prof. Dr. Laurent Gillet for providing the BoHV-4 strain V.test and Mab35 antibody. Further, we would like to thank Melanie Bauwens, Carine Boone, Nele Dennequin and Chantal Vanmaercke for their excellent technical assistance. This work was supported by the China Scholarship Council (201408650005).

\section{Author details}

1 Department of Virology, Parasitology and Immunology, Faculty of Veterinary Medicine, Ghent University, Salisburylaan 133, 9820 Merelbeke, Belgium.

2 Department of Reproduction, Obstetrics and Herd Health, Faculty of Veterinary Medicine, Ghent University, Salisburylaan 133, 9820 Merelbeke, Belgium.

\section{Publisher's Note}

Springer Nature remains neutral with regard to jurisdictional claims in published maps and institutional affiliations.
Received: 9 November 2018 Accepted: 10 January 2019

Published online: 08 February 2019

\section{References}

1. Davison AJ, Eberle R, Ehlers B, Hayward GS, McGeoch DJ, Minson AC, Pellett PE, Roizman B, Studdert MJ, Thiry E (2009) The order herpesvirales. Arch Virol 154:171-177

2. Bartha A, Juhasz M, Liebermann H (1966) Isolation of a bovine herpesvirus from calves with respiratory disease and keratoconjunctivitis. A preliminary report. Acta Vet Acad Sci Hung 16:357-358

3. Chastant-Maillard S (2015) Impact of bovine herpesvirus 4 (BoHV-4) on reproduction. Transbound Emerg Dis 62:245-251

4. Osorio FA, Rock DL, Reed DE (1985) Studies on the pathogenesis of a bovine cytomegalo-like virus in an experimental host. J Gen Virol 66:1941-1951

5. Jacquot J, Spilmont C, de Bentzmann S, Dupuit F, Puchelle E (1992) Structure and secretory functions of the respiratory epithelium. Arch Int Physiol Biochim Biophys 100:A41-A46

6. Van Cleemput J, Poelaert KCK, Laval K, Maes R, Hussey GS, Van den Broeck W, Nauwynck HJ (2017) Access to a main alphaherpesvirus receptor, located basolaterally in the respiratory epithelium, is masked by intercellular junctions. Sci Rep 7:16656

7. Staehelin LA (1974) Structure and function of intercellular junctions. Int Rev Cytol 39:191-283

8. Clayson ET, Compans RW (1988) Entry of simian virus 40 is restricted to apical surfaces of polarized epithelial cells. Mol Cell Biol 8:3391-3396

9. Blank CA, Anderson DA, Beard M, Lemon SM (2000) Infection of polarized cultures of human intestinal epithelial cells with hepatitis A virus: vectorial release of progeny virions through apical cellular membranes. J Virol 74:6476-6484

10. Chu JJ, Ng ML (2002) Infection of polarized epithelial cells with flavivirus West Nile: polarized entry and egress of virus occur through the apical surface. J Gen Virol 83:2427-2435

11. Fuller S, von Bonsdorff CH, Simons K (1984) Vesicular stomatitis virus infects and matures only through the basolateral surface of the polarized epithelial cell line, MDCK. Cell 38:65-77

12. Fuller SD, von Bonsdorff CH, Simons K (1985) Cell surface influenza haemagglutinin can mediate infection by other animal viruses. EMBO J 4:2475-2485

13. Donofrio G, Herath S, Sartori C, Cavirani S, Flammini CF, Sheldon IM (2007) Bovine herpesvirus 4 is tropic for bovine endometrial cells and modulates endocrine function. Reproduction 134:183-197

14. Donofrio G, Martignani E, Sartori C, Vanderplasschen A, Cavirani S, Flammini CF, Gillet $L$ (2007) Generation of a transposon insertion mutant library for bovine herpesvirus 4 cloned as a bacterial artificial chromosome by in vitro MuA based DNA transposition system. JVirol Methods 141:63-70

15. Yang B, Li Y, Bogado Pascottini O, Xie J, Wei R, Opsomer G, Nauwynck H (2017) Primary replication and invasion of the bovine gammaherpesvirus BoHV-4 in the genital mucosae. Vet Res 48:83

16. Galen B, Cheshenko N, Tuyama A, Ramratnam B, Herold BC (2006) Access to nectin favors herpes simplex virus infection at the apical surface of polarized human epithelial cells. J Virol 80:12209-12218

17. Reed $\sqcup$, Muench $H$ (1938) A simple method of estimating fifty per cent endpoints. Am J Epidemiol 27:493-497

18. Steukers L, Vandekerckhove AP, Van den Broeck W, Glorieux S, Nauwynck HJ (2012) Kinetics of BoHV-1 dissemination in an in vitro culture of bovine upper respiratory tract mucosa explants. ILAR J 53:E43-E54

19. Machiels B, Lete C, Guillaume A, Mast J, Stevenson PG, Vanderplasschen A, Gillet L (2011) Antibody evasion by a gammaherpesvirus O-glycan shield. PLoS Pathog 7:e1002387

20. Donofrio G, van Santen VL (2001) A bovine macrophage cell line supports bovine herpesvirus-4 persistent infection. J Gen Virol 82:1181-1185

21. Machiels B, Stevenson PG, Vanderplasschen A, Gillet L (2013) A gammaherpesvirus uses alternative splicing to regulate its tropism and its sensitivity to neutralization. PLoS Pathog 9:e1003753 
22. Frederico B, Milho R, May JS, Gillet L, Stevenson PG (2012) Myeloid infection links epithelial and B cell tropisms of Murid Herpesvirus-4. PLoS Pathog 8:e1002935

23. Gaspar M, May JS, Sukla S, Frederico B, Gill MB, Smith CM, Belz GT, Stevenson PG (2011) Murid herpesvirus-4 exploits dendritic cells to infect B cells. PLoS Pathog 7:e1002346

24. Lete C, Palmeira L, Leroy B, Mast J, Machiels B, Wattiez R, Vanderplasschen A, Gillet $L$ (2012) Proteomic characterization of bovine herpesvirus 4 extracellular virions. J Virol 86:11567-11580

25. Machiels B, Lete C, de Fays K, Mast J, Dewals B, Stevenson PG, Vanderplasschen A, Gillet L (2011) The bovine herpesvirus 4 Bo10 gene encodes a nonessential viral envelope protein that regulates viral tropism through both positive and negative effects. J Virol 85:1011-1024

26. Vandekerckhove AP, Glorieux S, Gryspeerdt AC, Steukers L, Duchateau L, Osterrieder N, Van de Walle GR, Nauwynck HJ (2010) Replication kinetics of neurovirulent versus non-neurovirulent equine herpesvirus type 1 strains in equine nasal mucosal explants. J Gen Virol 91:2019-2028

27. Volberg T, Geiger B, Kartenbeck J, Franke WW (1986) Changes in membrane-microfilament interaction in intercellular adherens junctions upon removal of extracellular Ca2+ ions. J Cell Biol 102:1832-1842

28. Milho R, Frederico B, Efstathiou S, Stevenson PG (2012) A heparandependent herpesvirus targets the olfactory neuroepithelium for host entry. PLoS Pathog 8:e1002986

29. Esclatine A, Bellon A, Michelson S, Servin AL, Quero AM, GeniteauLegendre M (2001) Differentiation-dependent redistribution of heparan sulfate in epithelial intestinal Caco-2 cells leads to basolateral entry of cytomegalovirus. Virology 289:23-33

30. Vanderplasschen A, Bublot M, Dubuisson J, Pastoret PP, Thiry E (1993) Attachment of the gammaherpesvirus bovine herpesvirus 4 is mediated by the interaction of gp8 glycoprotein with heparinlike moieties on the cell surface. Virology 196:232-240

31. de Lima BD, May JS, Stevenson PG (2004) Murine gammaherpesvirus 68 lacking gp150 shows defective virion release but establishes normal latency in vivo. J Virol 78:5103-5112

32. Gillet L, Adler H, Stevenson PG (2007) Glycosaminoglycan interactions in murine gammaherpesvirus-68 infection. PLoS One 2:e347

33. Gillet L, Colaco S, Stevenson PG (2008) The murid herpesvirus-4 gH/gL binds to glycosaminoglycans. PLoS One 3:e1669

34. Akula SM, Wang FZ, Vieira J, Chandran B (2001) Human herpesvirus 8 interaction with target cells involves heparan sulfate. Virology 282:245-255

35. Akula SM, Pramod NP, Wang FZ, Chandran B (2001) Human herpesvirus 8 envelope-associated glycoprotein B interacts with heparan sulfate-like moieties. Virology 284:235-249

36. Jarousse N, Chandran B, Coscoy L (2008) Lack of heparan sulfate expression in B-cell lines: implications for Kaposi's sarcoma-associated herpesvirus and murine gammaherpesvirus 68 infections. J Virol 82:12591-12597
Ready to submit your research? Choose BMC and benefit from:

- fast, convenient online submission

- thorough peer review by experienced researchers in your field

- rapid publication on acceptance

- support for research data, including large and complex data types

- gold Open Access which fosters wider collaboration and increased citations

- maximum visibility for your research: over 100M website views per year

At BMC, research is always in progress.

Learn more biomedcentral.com/submissions 